\title{
Rapid Assessment of Tree Debris Following Urban Forest Ice Storms
}

\author{
Richard J. Hauer, Angela J. Hauer, Dudley R. Hartel, and Jill R. Johnson
}

\begin{abstract}
This paper presents a rapid assessment method to estimate urban tree debris following an ice storm. Data were collected from 60 communities to quantify tree debris volumes, mostly from public rights-of-way, following ice storms based on community infrastructure, weather parameters, and urban forest structure. Ice thickness, area of a community, and street distance are significant predictors for estimating debris from ice storms. Results from this study provide a way to estimate woody debris volumes from urban trees immediately following an ice storm. The model can also be used to predict debris volumes for storm preparedness planning.

Key Words. Emergency Management; Ice Storm; Storm Damage; Tree Debris; Urban Forest.
\end{abstract}

The objective of this study was to develop a rapid assessment of ice storm damage in urban areas and generate a community- to regional-level estimate of tree debris volumes associated with clean-up and disposal. It is hypothesized that debris volumes are a function of weather events (ice thickness and wind), urban forest structure (percent tree canopy), community attributes (land area, street distance, population density), other unknown factors, and error (data measurement, recording, variability). The model ideally allows urban forest managers and emergency management personnel at local and regional levels to quickly and accurately estimate tree debris volumes after ice storms. Finally, the model can be used to predict debris volumes prior to storms and determine potential resource needs.

Ice storms occur annually and routinely damage trees in urban and rural areas (Hauer et al. 1993; Sisinni et al. 1995; Van Dyke 1999; Hooper et al. 2001; Changnon 2003; Hauer et al. 2006). The effect on urban tree damage varies from minor twig and branch breakage, to greater damage from bent or split stems, and extreme damage resulting from extensive canopy breakage to snapped and uprooted trees. Partially damaged trees may require removal soon after an ice storm, especially if deemed a high risk for failure (Hauer and Johnson 2003). Residual tree damage can last several years after an ice storm, requiring further tree maintenance or removal (Zipperer et al. 2004; Kraemer and Nyland 2009).

Several factors are associated with tree damage from ice storms. One factor is the accumulation of ice from freezing rain that increases with storm duration and precipitation (Yip 1995; Jones 1996). Ice accumulation is positively correlated with tree damage (Rebertus et al. 1997; Proulx and Greene 2001; Changnon 2003; Lafon 2004; Millward and Kraft 2004; Olthof et al. 2004; Hauer et al. 2006; Greene et al. 2007; Houston and Changnon 2007; Liu et al. 2008). Wind is another factor that is suggested to increase tree damage during ice storms; however, findings are inconsistent with no simple pattern emerging (Rogers 1922; Semonin 1978; Bruederle and Stearns 1985; De Steven et al. 1991; Jones 1996; Lafon et al. 1999; Proulx and Greene 2001, Millward and Kraft 2004; James et al. 2006; Greene et al. 2007; Houston and Changnon 2007). Many other tree factors that influence potential tree damage include tree species, branching architecture, wood physical properties, structural defects, tree size, and tree or stand density (Hauer et al. 1993; Sisinni et al. 1995; Rhoads et al. 2002; Millward and Kraft 2004; Hauer et al. 2006). The aspect, slope, and elevation of a site are also factors related to ice storm damage with these geographical features affecting ice accumulation (Siccama et al. 1976; Van Dyke 1999; Millward and Kraft 2004; Kenderes 2007; Stueve et al. 2007). Finally, as the spatial scale of the storm increases, the cumulative sum of damage increases (Van Dyke 1999; Jacobs 2000; Ciesla 2001).

\section{Damage Assessment and Debris Estimation After Ice Storms}

Communities face challenges to respond and recover from ice storms (Burban and Andresen 1994). Ideally, risk management plans should be in place prior to ice storms to address mitigation and prevention strategies, cover preparedness planning, and incorporate warning systems that predict the potential of a disaster (Hauer and Johnson 2003; Hauer et al. 2006; Godschalk et al. 2009). Implementing effective, efficient, equitable methods to assess the severity of tree damage and estimate tree debris is an important component of the response and recovery process (Bloniarz et al. 2001; FEMA 2007; Escobedo et al. 2009).

Tree damage assessment and debris management (e.g., estimation, collection and disposal) are some of the most challenging events following storms (FEMA 2007). Assessing tree dam- 
age requires trained people to evaluate tree damage, determine corrective actions, and estimate woody debris volumes. Existing debris estimation models and approaches vary in complexity, the time needed to implement, and the required skill level of the evaluator (King et al. 2007; Escobedo et al. 2009). On-theground approaches using sample plots or ocular estimates and remote sensing techniques using aerial sketchmapping, airborne videography, aerial photography, and satellite images are several ways to estimate damage following ice storms (Bruederle and Stearns 1985; De Steven et al. 1991; Hauer et al. 1993; Jacobs 2000; Bloniarz et al. 2001; Cielsa et al. 2001; Rhoads et al. 2002; Scarr et al. 2003; King et al. 2007; Stueve et al. 2007). These approaches have been used to estimate damage at regional, stand, and individual tree levels. Estimates are based on the percent reduction in canopy cover, change in stand composition, difference in vegetation vigor, basal area change, and comparison of pre- and post-storm inventories, and formulas. A rapid estimate within one day and ideally within 12 hours of the storms' end is important for emergency planners to rate recovery needs and mobilize fiscal, human, and equipment resources where necessary (Bloniarz et al. 2001; FEMA 2007). Rapid assessment approaches support quick evaluation to determine if state and federal disaster declarations are appropriate.

Estimates of debris volumes following ice storms can be generated using a street-segment based approach (Bloniarz et al. 2001). This approach can be performed either by collecting a statistical sample in the field or estimating with i-Tree, using the Storm Damage Assessment Protocol (Bloniarz et al. 2001). Ideally, the i-Tree approach uses pre-storm sample plots to predict tree debris. The United States Army Corps of Engineers has also generated ice storm tree debris estimates using methods adapted from hurricane tree debris estimation models (Escobedo et al. 2009).

\section{Ice Storm Frequency and Severity}

Ice storms are common to the eastern region of the United States. Other locations (e.g., inland parts of the U.S. Pacific Northwest and parts of Europe) also experience these storms (Sanzen-Baker and Nimmo 1941; Irland 2000; Hauer et al. 2006; Kenderes et al. 2007). The U.S. National Weather Service defines an ice storm as $6.35 \mathrm{~mm}$ or more of ice thickness on surfaces from freezing rain (Irland 2000). The geographical extent of ice storms varies from a localized to widespread area (Hauer et al. 2006). The severity of extreme widespread ice storms, such as the 1998 North American ice storm, can exceed several billion U.S. dollars in losses. Annual losses in the U.S. from ice storms are estimated at USD \$226 million (Changnon and Changnon 2002; Changnon 2003). Depending on the location, the mean time for major ice storms to reoccur is between 20 and 100 years (Melancon and Lechowicz 1987; DeGaetano 2000; Pasher and King 2006). Extreme ice storms, such as the 1998 North American ice storm in the northeastern United States, are estimated to return once every 220 to 290 years (Proulx and Greene 2001). Whether localized or widespread, damage to electric distribution systems, blocked roadways, and property damage from fallen trees and limbs pose significant safety concerns and disrupt normal community functions. The time to recover from ice storms may take longer in more rural areas, especially the repair of downed electrical systems (Call 2010).

\section{MATERIALS AND METHODS}

\section{Data Sources}

A list of communities from 15 eastern U.S. states that experienced ice storms was developed based on the experience of the authors and the respective state Urban \& Community Forestry (U\&CF) coordinators. Federal Emergency Management Agency (FEMA) declarations of winter storms were viewed online (www.fema.gov/ news/disasters.fema) and ice storm disaster locations recorded to further determine potential study sites. Targeted communities were sent a questionnaire and asked to supply information about ice storms since 2000; severity of the ice storm based on ice thickness and maximum wind speed during the ice storm; how much private land debris, public land debris, and total tree debris was collected; and a description of their urban forest structure including percent canopy cover and urban forest species composition.

The questionnaire served as an initial source for collecting community data using a repeated contact approach (Dillman 2007). Each community was contacted up to four times to elicit a response, by regular mail, e-mail, and phone. A letter and questionnaire were sent by e-mail in early March 2010 to communities with known e-mail addresses, or regular mail to those with no known e-mail address. A reminder postcard was sent two weeks later to all communities with a state U\&CF coordinator supplied postal street address or an e-mail reminder to those without a street address. A third contact was made at the end of March by phone call to all nonrespondents, followed by a final fourth contact and questionnaire in April to those that had still not responded. A second wave of questionnaires was sent starting in early April to more communities whose contact information was later received. Questionnaire delivery used the previously described methods and commenced in early May 2010.

Once surveys were received, any missing information was sought. Cities were first contacted for clarification of data or asked directly for missing data. Further, missing city data was located online through the official city website or other online means (i.e., www.city-data.com/city). Missing weather information (ice thickness and wind speed) was located principally through collected data of the National Oceanic and Atmospheric Administration (U.S.) (www.weatherpages.com/wxhistory.html). Various other websites were searched for data and clarification on specific ice storms. Additional data developed from the $30 \mathrm{~m}$ resolution 2001 National Land Cover Database (NLCD) for tree canopy, population, and land area were collected for responding communities for the urban forest data interface, from the USDA Northern Research Station (http://nrs.fs.fed.us/data/urban) (Nowak 2010).

Descriptive statistics and multiple regression modeling used SPSS version 18.0. A multiple regression model was created to test the a priori hypothesized relationship between the dependent variable (tree debris volume, $\mathrm{m}^{3}$ ) and four independent variables (ice thickness, $\mathrm{cm}$; maximum wind speed, $\mathrm{km} / \mathrm{h}$; percent tree canopy, and community infrastructure). The community infrastructure variables (public linear street distance, $\mathrm{km}$; total community land area, $\mathrm{km}^{2}$; total land area, $\mathrm{km}^{2}$; and developed land area, $\mathrm{km}^{2}$ ) were each tested individually in preliminary separate regression models (Appendix).

Significance for all tests used an $\alpha \leq 0.05$ significance level. Potential outliers within the multiple regression model were discerned using the Mahalanobis distance procedure at the $<0.001$ 
significance level and none were found (Mertler and Vannatta 2005). Assumptions of normality, linearity, and homoscedasticity were tested using bivariate plots between independent and dependent variables, a plot of the standardized residuals and standardized predicted values from the final multiple regression model, and Box's Test for Equality of Covariance Matrices. The variance inflation factor (VIF) statistic was used to test for multicollinearity and this was interpreted as occurring with a VIF $\geq$ 10 (Neter et al. 1990; Mertler and Vannatta 2005). Tulsa, Oklahoma, U.S., was identified as an extreme value, and two final models were created (Mertler and Vannatta 2005). The Tulsa data were considered an extreme location based on the much larger size of the community and volume of debris generated relative to other communities in the model. The Tulsa data were comparable to other locations when debris volumes were normalized by community area or street distance and compared to other study sites. Creating separate models is an accepted way to account for an extreme case that likely reflects a valid observation (Mertler and Vannatta 2005). Two cases (Springfield, Missouri and Saint Louis, Missouri, U.S.) were removed after initial modeling and casewise diagnostics indicated these as outliers based on the residual exceeding three standard deviations. A third normalized model (debris volume per community infrastructure attribute) was developed and no study sites were found as outliers.

\section{RESULTS}

\section{Survey Response}

There were 298 communities targeted in 15 states with potential ice storm data. A total 132 communities responded (44\% response rate) with $71(54 \%)$ of these reporting ice storms while the remaining $61(46 \%)$ had not encountered any ice storms since January 1 , 2000. However, of the 71 communities that had ice storms, only 60 returned usable data. Several communities that were unable to respond provided reasons including an inability to locate the data, staff changes, small community with few staff, and/or not enough labor to follow through with the debris estimations and recording at the time of the storm. Some communities may have ice storm data, but indicated they were short of staff or that other job duties prevented them from completing the questionnaire. Of the 60 communities that responded, four communities completed two surveys (one per storm), thus 64 ice storms were reported.

\section{Model Data and Debris Volumes Estimation}

Pearson correlations coefficients suggested strong fits between debris volumes and all community infrastructure variables, which are street miles (0.909), total community land area (0.828), total 2001 NLCD land area (0.877), and developed land area (0.866). Simply put, the larger the area or street distance, the greater volume of debris. No simple relationships were found for the urban forest weather (ice and wind) or structure attribute (canopy cover) and debris volumes. Proportionally adjusting (normalized) debris by street distance or land area resulted in strong correlations between the volume of debris per street distance (0.616) and ice thickness or volume of debris per land area (0.534) and ice thickness. Negative correlations between wind speed and debris volume per land area per ice thickness $(-0.373)$ and between wind speed and debris volume per street distance per ice thickness (-0.373) were detected. No significant relationship between canopy cover and nonnormalized or normalized debris volumes were found.

Forty communities provided sufficient data (e.g., debris volume estimates, community infrastructure, weather parameters) from an ice storm to include in the authors' models. The mean debris collected was $145,218 \mathrm{~m}^{3}$ per ice storm (Table 1). By street distance, this mean was $179.8 \mathrm{~m}^{3} / \mathrm{km}$ and by land area the mean was $1172 \mathrm{~m}^{3} / \mathrm{km}^{2}$ of debris reported by storm. Responding towns experienced a mean of $3.6 \mathrm{~cm}$ of ice thickness that was between $0.4 \mathrm{~cm}$ and $12.7 \mathrm{~cm}$. The maximum wind speed during the ice storm was a mean $28.8 \mathrm{~km} / \mathrm{h}$ with reported values between $5 \mathrm{~km} / \mathrm{h}$ and $64 \mathrm{~km} / \mathrm{h}$. A few communi-

Table 1. Descriptive statistics from all model communities $(n=40)$.

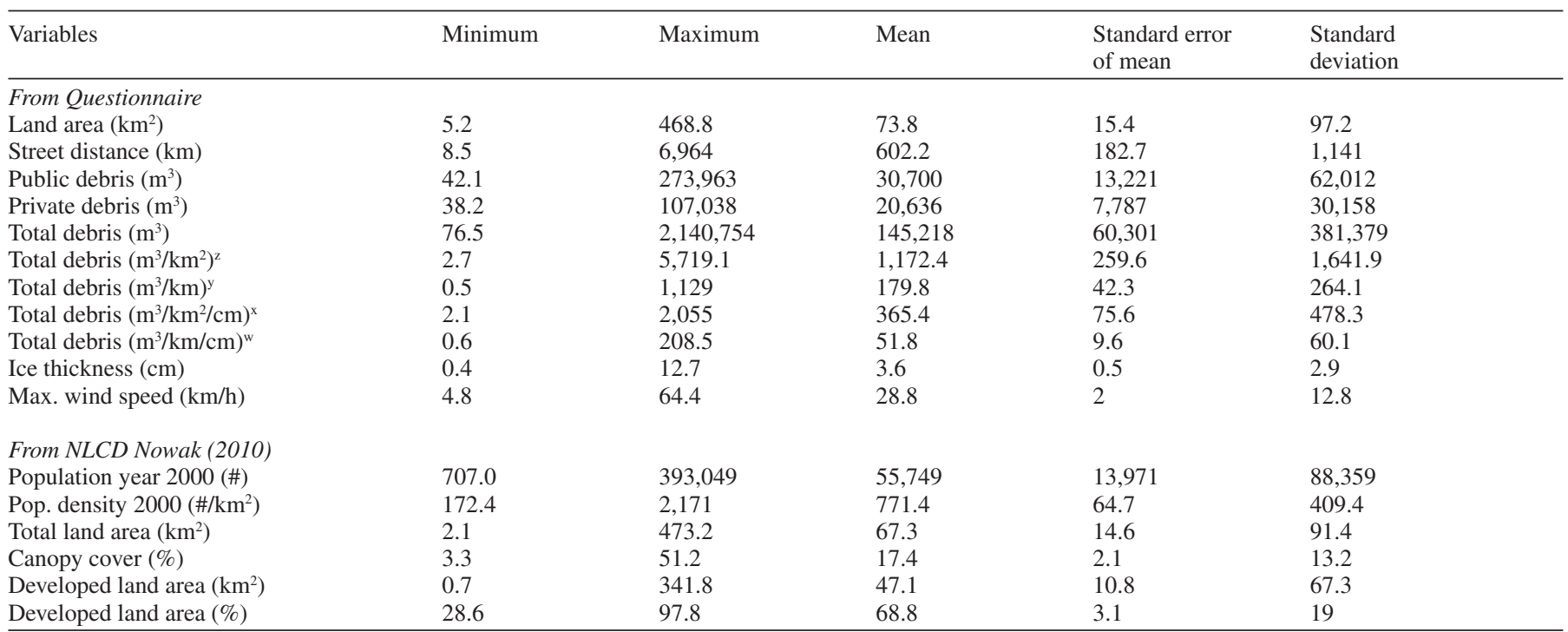

${ }^{\mathrm{z}}$ Total debris/land area

y Total debris/street distance

x Total debris/land area/ice thickness

w Total debris/street distance/ice thickness 
ties $(15 \%)$ were able to report canopy cover and approximately half of these provided an educated estimate. Estimates of canopy cover used the 2001 NLCD dataset and a mean of $17.4 \%$ for communities in this study was found with canopy values between $3.3 \%$ and $51.2 \%$. Accounting for debris volume per $\mathrm{cm}$ of ice and community infrastructure, $51.8 \mathrm{~m}^{3}$ of debris per $\mathrm{km}$ street distance per $\mathrm{cm}$ of ice $\left(276.9 \mathrm{yd}^{3} / \mathrm{mi} / \mathrm{in}\right)$ occurred. On a community land area basis, this was $365.4 \mathrm{~m}^{3} / \mathrm{km}^{2} / \mathrm{cm}(3143.2$ $\mathrm{yd}^{3} / \mathrm{mi}^{2} / \mathrm{in}$ ). More than $80 \%$ (33) of the communities were declared a Federal Emergency Management Agency disaster area.

The initial model of hypothesized indicators provided significant $(P<0.001)$ and strong evidence $\left(\mathrm{R}^{2}\right.$ adj $\left.=0.949\right)$ for predicting debris volume. Street miles and ice thickness were both significant predictors of debris volume (Table 2). Land area, 2001 NLCD total land area, and 2001 NLCD developed land area were also significant predictors, yet not as strong as street distance. Maximum wind speed, canopy cover, and interaction among variables showed no relationship to the debris volumes. The final estimation model of debris from an ice storm is

[1] Debris Volume $\left(\mathrm{m}^{3}\right)=-99,136+311.2 \cdot$ Street Distance $(\mathrm{km})+15,031.9 \bullet$ Ice Thickness $(\mathrm{cm})$

Debris Volume $\left(\mathrm{yds}^{3}\right)=-129,677+655.1 \cdot$ Street

Distance (mi) + 49,426.5 • Ice Thickness (in)

A second model was created that excluded Tulsa, OK (Table 3 ). This model location had approximately twice the volume of debris - 2.1 million $\mathrm{m}^{3}$ - as the next largest site and over a magnitude greater than the mean debris volumes from these storms. This model was also highly significant $(P<0.001)$ and provided strong evidence $\left(\mathrm{R}_{\text {adj }}^{2}=0.792\right)$ for the predictors total community land area and ice thickness to estimate debris volumes in communities after an ice storm. Street distance and other community infrastructure variables were also significant predictors; however, they were not as strong as that of land area. Again, maximum wind speed, canopy cover, or interactions among variables were not significant. The final estimation model (without Tulsa and the two previously reported outliers) that predicts debris from an ice storm is
[2] Debris Volume $\left(\mathrm{m}^{3}\right)=-63,346+1,571.4 \cdot$ Land Area $(\mathrm{km})$ $+12,832.2 \cdot$ Ice Thickness $(\mathrm{cm})$

Debris Volume $\left(\mathrm{yds}^{3}\right)=-82,529+5,314.4 \cdot$ Land Area $(\mathrm{mi})$ $+41,651.5 \cdot$ Ice Thickness (in)

A third debris estimation model was created by normalizing debris on a per unit (street distance and land area) basis. Street distance was a better model predictor than land area (Table 4). This model was significant $(P<0.0 .001)$ with a lower $\mathrm{R}^{2}\left(\mathrm{R}^{2}\right.$ $=0.439$ ) than the nonnormalized models. No sites were found as outliers with this approach. Ice thickness was again a significant predictor. Maximum wind speed and canopy were not significant. A significant interaction between ice thickness and wind speed was found. The intercept term was not significant and excluded in the final selected model. Thus, on a debris per street distance basis, the final model $\left(\mathrm{R}_{\text {adj }}^{2}=0.642\right)$ is

[3] Debris Volume per street distance $\left(\mathrm{m}^{3} / \mathrm{km}\right)=100.3$

- Ice Thickness $(\mathrm{cm})-1.7 \bullet$ Ice Thickness $(\mathrm{cm})$

- Maximum Wind Speed $(\mathrm{km} / \mathrm{h})$

Debris Volume per Street Distance $\left(\mathrm{yd}^{3} / \mathrm{mi}\right)=535.9$

- Ice Thickness (in) - 14.6 - Ice Thickness (in)

- Maximum Wind Speed (mph)

\section{Comparison of Model-Predicted Values and Reported Debris Volumes}

A graphical comparison of all three models was constructed to compare predicted values with actual reported values (Figure 1; Figure 2; Figure 3; Figure 4; Figure 5). Both models one and two had a tendency to under predict for smaller communities, produce estimates that neither consistently over or under predict for medium-sized communities, and more likely to over predict for larger communities. Model two appears to represent actual predictions better for smaller communities with fewer street miles $(\leq 161 \mathrm{~km})$. In contrast, model one appears better suited

Table 2. Estimation of tree debris following an ice storm from model one (full and final models without Springfield, MO and St. Louis, MO).

\begin{tabular}{|c|c|c|c|c|c|c|c|}
\hline \multirow[b]{2}{*}{ Model variables } & \multicolumn{2}{|c|}{$\begin{array}{c}\text { Unstandardized } \\
\text { Coefficients }\end{array}$} & \multirow{2}{*}{$\begin{array}{c}\text { Standardized } \\
\text { Coefficients }\end{array}$} & \multicolumn{2}{|c|}{ t-test Statistics } & \multicolumn{2}{|c|}{ Correlations } \\
\hline & $\mathrm{B}$ & Std. error & & t-value & Sig. & Zero-order & Partial \\
\hline (Intercept) & $-1,312,401$ & $58,887.6$ & -2.229 & 0.034 & & & \\
\hline Street Distance $(\mathrm{km})$ & 311.981 & 12.683 & 0.986 & 24.598 & 0.000 & 0.968 & 0.977 \\
\hline Ice Thickness $(\mathrm{cm})$ & $16,732.6$ & 5078.06 & 0.136 & 3.295 & 0.003 & 0.002 & 0.522 \\
\hline Max. Wind Speed $(\mathrm{km} / \mathrm{h})$ & -58.31 & 1351.81 & -0.002 & -0.043 & 0.966 & -0.110 & -0.008 \\
\hline Canopy Cover $(\%)$ & 1603.07 & 1278.73 & 0.053 & 1.254 & 0.220 & -0.003 & 0.227 \\
\hline \multicolumn{8}{|c|}{ Final a priori model $\left(R^{2}=0.952, R_{a d j}^{2}=0.949\right.$, std. error of est. $\left.=82566 F(2,33)=328.9 p<0.000\right)$} \\
\hline (Intercept) & $-99,136$ & $23,426.8$ & & -4.232 & 0.000 & & \\
\hline Street Distance $(\mathrm{km})$ & 311.169 & 12.133 & 0.985 & 25.647 & 0.000 & 0.968 & 0.976 \\
\hline Ice Thickness $(\mathrm{cm})$ & $15,031.9$ & 4606.00 & 0.125 & 3.264 & 0.003 & -0.007 & 0.494 \\
\hline
\end{tabular}


Table 3. Estimation of tree debris following an ice storm from model two (full and final models without Springfield, MO; St. Louis, MO; and Tulsa, OK).

\begin{tabular}{|c|c|c|c|c|c|c|c|}
\hline \multirow[b]{2}{*}{ Model Variables } & \multicolumn{2}{|c|}{$\begin{array}{l}\text { Unstandardized } \\
\text { Coefficients }\end{array}$} & \multirow{2}{*}{$\begin{array}{c}\text { Standardized } \\
\text { Coefficients } \\
\text { Beta }\end{array}$} & \multicolumn{2}{|c|}{ t-test Statistics } & \multicolumn{2}{|c|}{ Correlations } \\
\hline & B & Std. Error & & t-value & Sig. & Zero-order & Partial \\
\hline (Intercept) & $-55,537.6$ & $40,229.5$ & & -1.381 & 0.178 & & \\
\hline Land Area $\left(\mathrm{km}^{2}\right)$ & 1523.49 & 153.196 & 0.851 & 9.945 & 0.000 & 0.840 & 0.879 \\
\hline Ice Thickness $(\mathrm{cm})$ & $13,705.9$ & 3476.46 & 0.326 & 3.942 & 0.000 & 0.221 & 0.591 \\
\hline Canopy Cover $(\%)$ & 534.935 & 911.105 & 0.052 & 0.587 & 0.562 & 0.285 & 0.108 \\
\hline \multicolumn{8}{|c|}{ Final a priori model $\left(R^{2}=0.804, R_{a d j}^{2}=0.792\right.$, std. error of est. $\left.=57295, F(2,33)=67.594, p<0.000\right)$} \\
\hline (Intercept) & $-63,345.8$ & $17,475.1$ & & -3.625 & 0.001 & & \\
\hline Land Area $\left(\mathrm{km}^{2}\right)$ & 1571.39 & 138.987 & 0.878 & 11.306 & 0.000 & 0.841 & 0.892 \\
\hline Ice Thickness (cm) & $12,832.2$ & 3184.83 & 0.313 & 4.029 & 0.000 & 0.209 & 0.574 \\
\hline
\end{tabular}

Table 4. Estimation of tree debris following an ice storm from model three (normalized models).

\begin{tabular}{|c|c|c|c|c|c|c|c|}
\hline \multirow[b]{2}{*}{ Model Variables } & \multicolumn{2}{|c|}{$\begin{array}{l}\text { Unstandardized } \\
\text { Coefficients }\end{array}$} & \multirow{2}{*}{$\begin{array}{l}\text { Standardized } \\
\text { Coefficients } \\
\text { Beta }\end{array}$} & \multicolumn{2}{|c|}{ t-test Statistics } & \multicolumn{2}{|c|}{ Correlations } \\
\hline & $\mathrm{B}$ & Std. error & & t-value & Sig. & Zero-order & Partial \\
\hline (Intercept) & -179.593 & 199.554 & & -0.900 & 0.375 & & \\
\hline Ice Thickness (cm) & 148.694 & 46.328 & 1.631 & 3.210 & 0.003 & 0.619 & 0.506 \\
\hline Max. Wind Speed $(\mathrm{km} / \mathrm{h})$ & 3.690 & 5.766 & 0.173 & 0.640 & 0.527 & -0.288 & 0.116 \\
\hline Ice $\bullet$ Wind $(\mathrm{cm} \bullet \mathrm{km} / \mathrm{h})$ & -3.205 & 1.565 & -1.078 & -2.048 & 0.049 & 0.327 & -0.350 \\
\hline Ice $\bullet$ Canopy $(\mathrm{cm} \bullet \%)$ & -0.669 & 1.357 & -0.146 & -0.493 & 0.626 & 0.265 & -0.090 \\
\hline Wind • Canopy $(\mathrm{km} / \mathrm{h} \bullet \%)$ & 0.067 & 0.184 & 0.139 & 0.364 & 0.719 & -0.185 & 0.066 \\
\hline \multicolumn{8}{|c|}{ Final a priori model $\left(R^{2}=0.661, R_{a d j}^{2}=0.642\right.$, std. error of est. $\left.=191.6 F(2,36)=25.421 p<0.000\right)$} \\
\hline Ice Thickness (cm) & 100.277 & 17.589 & 1.469 & 5.701 & 0.000 & 0.760 & 0.689 \\
\hline Ice $\bullet$ Wind $(\mathrm{cm} \bullet \mathrm{km} / \mathrm{h})$ & -1.696 & 0.571 & -0.766 & -2.971 & 0.005 & 0.595 & -0.444 \\
\hline
\end{tabular}

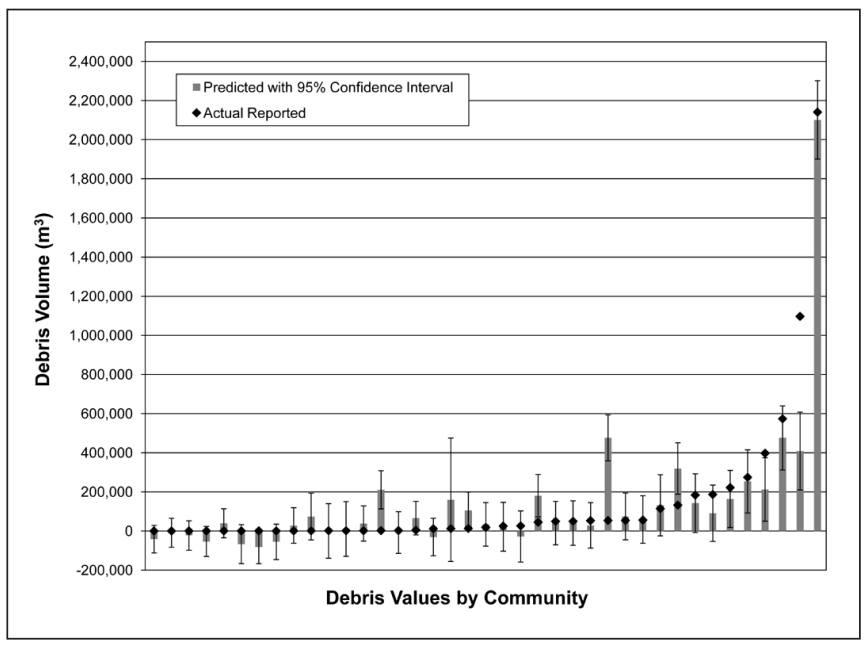

Figure 1. Comparison between actual reported and predicted tree debris volumes with $95 \%$ confidence intervals (bars) from model one (street distance and ice thickness).

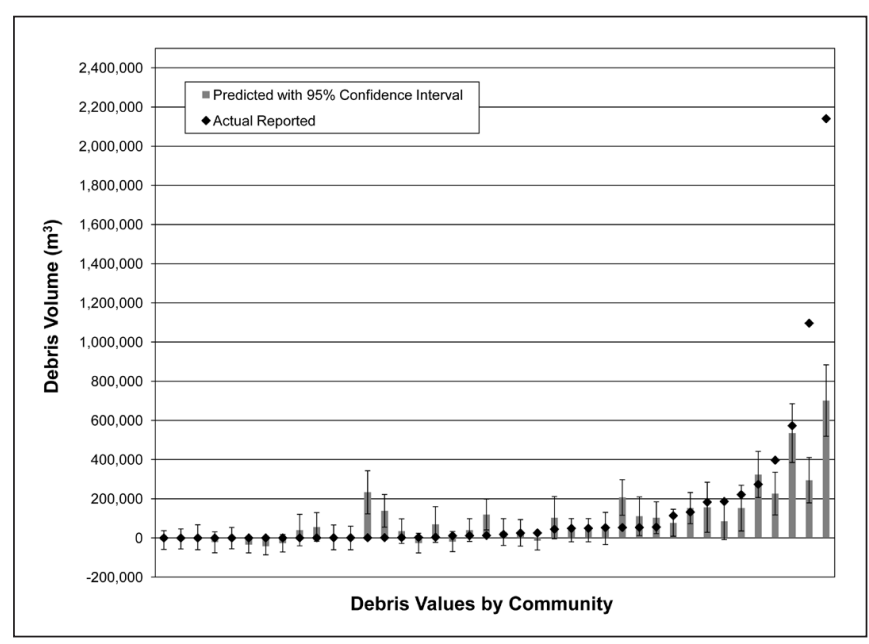

Figure 2. Comparison between actual reported and predicted tree debris volumes with $95 \%$ confidence intervals (bars) from model two (land area and ice thickness). 


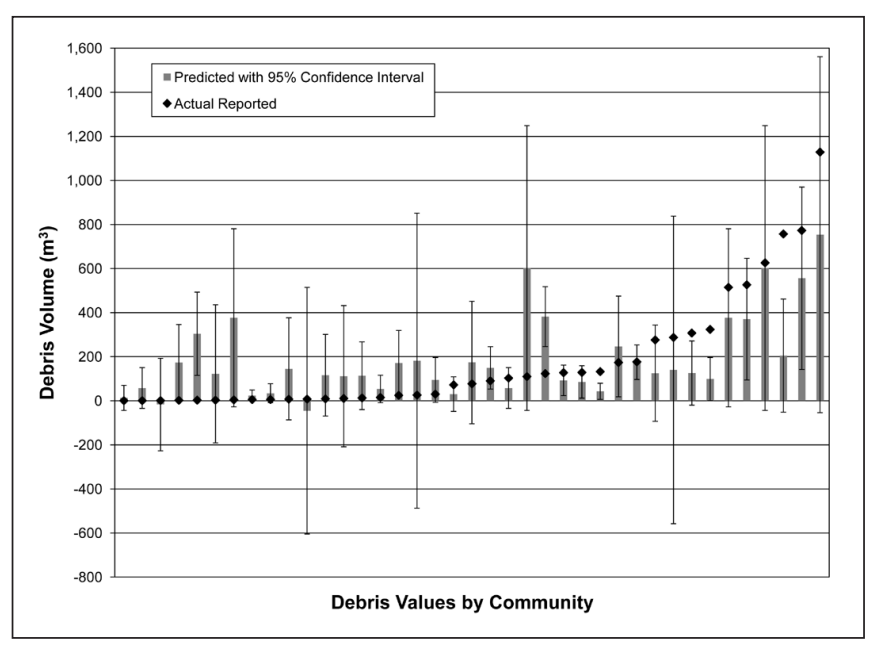

Figure 3. Comparison between actual reported and predicted tree debris volumes with $95 \%$ confidence intervals (bars) from model three (normalized by street distance, thickness and ice $X$ wind interaction).

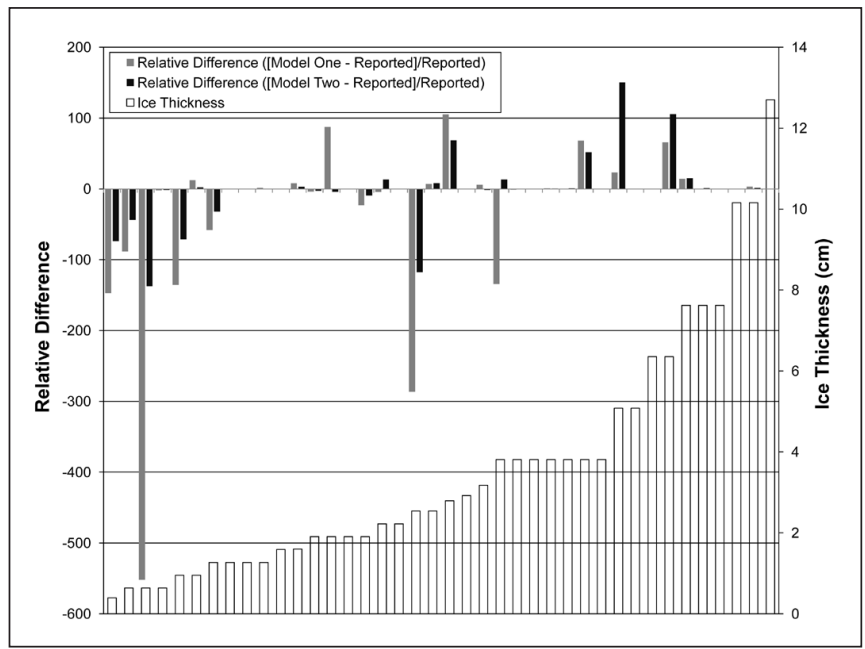

Figure 4. Relative comparison between reported and predicted debris volumes from models one and two compared to ice thickness.

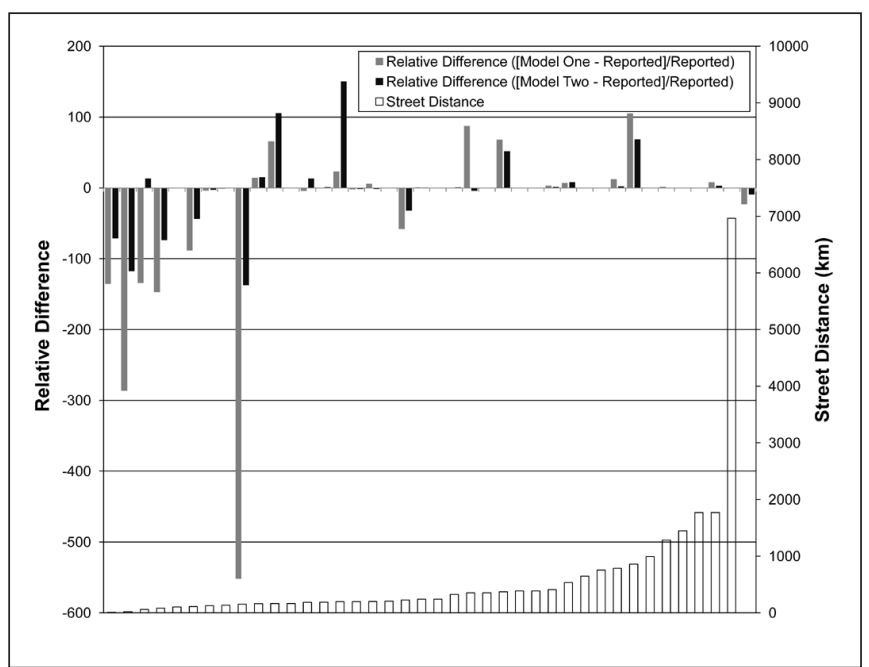

Figure 5. Relative comparison between reported and predicted debris volumes from models one and two compared to street distance.

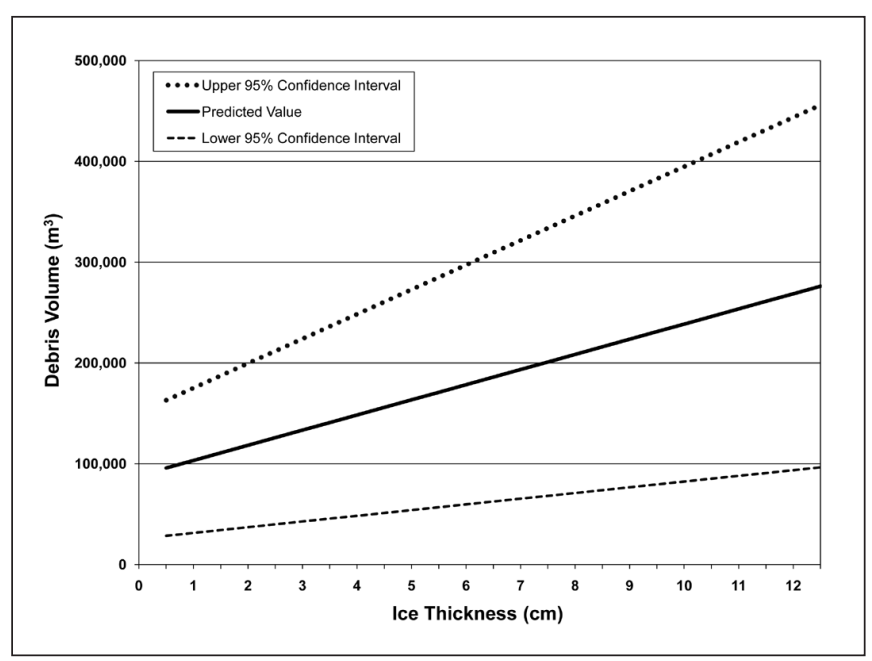

Figure 6. Prediction of tree debris volumes for the mean community size (land area $=73.8 \mathrm{~km}^{2}$, street distance $=602 \mathrm{~km}$, and population $=55,750$ people) from this study with upper and lower $95 \%$ confidence intervals.

for larger communities ( $\geq 354 \mathrm{~km})$. Model three results are more variable with no over or under prediction patterns discerned.

More than half $(53 \%)$ of model three predictions were outside of the $95 \%$ confidence interval. Model one and two were much better at predicting reported results within $95 \%$ confidence intervals. Model one had $92 \%$ of the predictions within these bounds as compared to $79 \%$ with model two. Figure 6 provides an example of developing a tree debris estimation for a community at potential levels of ice thickness to prepare for ice storms.

\section{DISCUSSION AND CONCLUSION}

Damage to trees and forests from ice storms has been reported in the scientific literature dating back more than 100 years (Harshberger 1904; Van Dyke 1999; Hauer et al. 2006). Over this time frame and from over one hundred published reports, predictable patterns have emerged. Within forest ecosystems, ice storms regularly cause disturbance regimes that favor some tree species, reduce the importance of others species, and add woody debris to the forest floor (Melancon and Lechowicz 1987; Lafon 2004). Tree species vary in their susceptibility or resistance to damage (Van Dyke 1999; Hauer et al. 2006). Resulting damage is soon evident after ice storms with broken canopies, snapped stems, whole tree failures, and ultimately piles of debris. The residual effects of ice storms can last for several years after the storm passes with tree defects requiring corrective action (Zipperer et al. 2004). Of interest in the short-term, however, is determining how much damage occurred, how long it will take to clean up, and what will it cost.

Tree debris volume $\left(\mathrm{m}^{3}\right)$ is commonly used as a measure to develop time and cost projections of a storm (Bloniarz et al. 2001; FEMA 2007; Escobedo et al. 2009). An accurate estimate of debris volume is an important part to systematically initiate response and recovery plans. For example, Barber (2008) reported debris volumes from a 2007 ice storm with initial estimates of 611,644 $\mathrm{m}^{3}$, and the final 2,064,298 $\mathrm{m}^{3}$ of collected tree debris was over three times greater. These estimates are also a vital part to help determine if the storm meets state and federal disaster declaration criteria and if so, to secure declaration and debris removal and 
restoration funding based on the severity of the storm. The vast majority of the model sites in this study were declared FEMA disaster sites. Debris eligible for FEMA reimbursement is that from the public right-of-way with some private debris collected when brought and dumped on the public right-of-way (FEMA 2007). Models from this study were developed with this in mind.

Ice thickness was a significant variable when explaining tree debris volumes following ice storms in this study. This result is not surprising and is consistent with several past research results that documented a positive relationship between tree damage and ice accumulation (Jones 1996; Van Dyke 1999; Hauer et al. 2006; Liu et al. 2008). Lafon (2004) developed a model showing a strong relationship $\left(\mathrm{R}^{2}=0.83\right)$ between the proportion of trees damaged in forests and ice thickness, $y=-0.0696+0.0154 x$, where $\mathrm{y}=$ Proportion of Trees Damaged and $\mathrm{x}=$ Ice Thickness (mm). Most ice storms result in a mean of $1 \mathrm{~cm}$ of ice thickness (Changnon 2003). A typical ice storm event thus only coincides with $10 \%$ or fewer trees damaged in a forest. In contrast, from this study, approximately half of the trees would be damaged across all study sites based on a mean ice thickness of $36 \mathrm{~mm}$, assuming rural forest structure and urban forest structure were equivalent.

Mean debris volumes from this study fell within ranges reported in urban and rural forests following ice storms. Bloniarz et al. (2001) reported that debris estimates per street distance were between 0 and $301 \mathrm{~m}^{3} / \mathrm{km}$ for streets with no ( 0 trees per $\left.\mathrm{km}\right)$ to very high tree density ( 243 to 322 trees per $\mathrm{km}$ ) for an average ice storm event. These estimates range from 0 to $552 \mathrm{~m}^{3} / \mathrm{km}$ for no to severe $(\geq 75 \%)$ canopy loss. A mean of $180 \mathrm{~m}^{3} / \mathrm{km}$ of debris occurred during storms at the study sites and were within this range. Ninety percent of reported debris volumes from locations in this study fell within the ranges reported by Bloniarz et al. (2001).

Within forest stands, debris volumes of 5.1, 19.4, 33.6, and $134 \mathrm{~m}^{3} / \mathrm{ha}$ have been reported (Bruederle and Stearns 1985; Rebertus et al. 1997; Hopper et al. 2001; Ryall and Smith 2005). Normalizing these ice storm events by debris volume, land area, and ice thickness, debris amounts were 2.04, 1.52, 3.57 , and $22.3 \mathrm{~m}^{3} / \mathrm{ha} / \mathrm{cm}$, respectively. The $134 \mathrm{~m}^{3} / \mathrm{ha}$ debris estimate is nearly a magnitude different, and when excluded, the remaining three reports averaged $2.38 \mathrm{~m}^{3} / \mathrm{ha} / \mathrm{cm}$. Current study sites had a mean debris volume of $11.72 \mathrm{~m}^{3} /$ ha or 3.26 $\mathrm{m}^{3} / \mathrm{ha} / \mathrm{cm}$ and are reasonable with reports from forest stands.

Wind alone was not a significant variable in estimating debris from this study. This is contrary to other studies that suggest wind direction, exposure, and increased drag exacerbates tree damage (Harshberger 1904; Semonin 1978; Bruederle and Stearns 1985; Millward and Kraft 2004; Greene et al. 2007; Houston and Changnon 2007). There may be several reasons for this result. First, wind and tree response is dynamic and not necessarily a simple relationship between wind speed and damage (James et al. 2006). Second, wind speed data only reflected the time period during the ice storm. Average wind speeds during ice storms are often reported as calm to moderate with only $4 \%$ of wind speeds greater than $32 \mathrm{~km} / \mathrm{h}$ (Houston and Changnon 2007). Third, the maximum wind speeds at the 40 study locations averaged $29 \mathrm{~km} / \mathrm{h}$, which is consistent with moderate breezes on the Beaufort scale (Cullen 2002). Luley et al. (2002a) found few significant branch failures with wind gusts below $64.4 \mathrm{~km} / \mathrm{h}$. They expect more frequent branch failures as wind gusts exceed $80.5 \mathrm{~km} / \mathrm{h}$ during the leafy period. Little tree damage below 50 $\mathrm{km} / \mathrm{hr}$ occurred during Hurricane Hugo (Francis and Gillespie
1993). Only two locations (both $64 \mathrm{~km} / \mathrm{h}$ ) in the current study approached the lower threshold for wind damage during the leafy period from these examples. Further, the deciduous trees were during their leafless period during the icing events. Luley et al. (2002a) found no consistent relationship between wind and tree damage in the leafless period and stated ice, sleet, or snow loads are probably more important with branch failures in the leafless period than wind alone. Finally, Kane (2008) reported the main cause of tree failure is extreme wind speed $>30 \mathrm{~m} / \mathrm{s}(108 \mathrm{~km} / \mathrm{h})$, which exceeded the wind speeds at the authors' study locations.

Even though this study did not find significant relationships between tree debris and wind during ice storms, wind plays a role in ice accumulation on surfaces. Rogers' (1922) early observations found greater accumulation of ice on the windward side of forests in a study site. More recently, a significant two times more macrolitter from an ice storm was recorded on the windward side 23.9 $\mathrm{m}^{3} / \mathrm{ha}$ than the leeward side $11.0 \mathrm{~m}^{3} / \mathrm{ha}$ of a forest (Bruederle and Stearns 1985; De Steven et al. 1991). As wind speed increases ice accumulation increases (Yip 1995; Jones 1996; Jones 1998; Lafon et al. 1999; Greene et al. 2007; Houston and Changnon 2007). Thus, wind may play a role in enhancing damage with severe wind speeds; however, its role with increased ice accumulation is possibly a better explanation for damage. An explanation for the negative interaction of ice thickness and wind speed from this study was not discerned. The effect of wind gusts and wind duration after the ice storm ended could represent forces resulting in tree damage and debris, but such data were not collected in this study.

Canopy cover is commonly used to describe the urban land area covered by tree and shrub canopies (Walton et al. 2008). Its relationship has been explored for ecological perspectives, demographics, urban forest structure, geographic features, and property values (Zipperer et al. 1997; Heynen and Lindsey 2003; Sander et al. 2010). Bloniarz et al. (2001) used canopy loss as a means of estimating debris from an ice storm. Escobedo et al. (2009) reported canopy cover was related to debris volumes from hurricane winds. The relationship was complex and no significant interactions between wind speed and canopy cover, or among canopy cover, wind speed, and developed urban cover, were found. No relationship between percentage canopy cover and debris was found in this study, contrary to the hypothesized positive relationship. Nor were any interactions between canopy cover and other study variables found. One explanation was that more than $70 \%$ of study sites had less than $20 \%$ canopy cover and possibly a uniform tree structure masked a putative relationship between canopy cover and tree debris that was primarily from the public right-of-way.

The study authors' initial approach to use community supplied estimates of canopy cover produced poor results with only $15 \%$ providing data of low quality, so the 2001 NLCD canopy cover was used to estimate community canopy cover. These NLCD values had a tendency to underestimate actual canopy coverage, which may have influenced the results (Walton 2008; Walton et al. 2008). Estimating canopy cover from other means should be done, but was beyond the scope of this study.

Some limitations of the models presented in this paper exist. First, incorporating an ice storm susceptibility index of tree species into the study was attempted (Hauer et al. 2006). The index ranks the potential susceptibility of the urban forest to an ice storm based on the existing tree structure. Communities were unable to provide reliable estimates of their street tree or community-wide urban forest structure. More than $60 \%$ did pro- 
vide some information about their public urban tree population; however, only seven communities provided data to potentially create a species ice storm susceptibility index. Incorporating coefficients for tree size and tree defects, two known factors related to failure from ice storms, should further increase the predictive power of the model. Again, communities as a whole were unable to provide this data and the scope of the project did not allow the collection of such. Finally, tree maintenance activities and type of pruning method used may affect susceptibility; however, clear support for this is lacking (Luley et al. 2002b).

Bond (2005) and Escobedo et al. (2009) provided estimates for debris removal costs for ice storms and hurricanes. They reported values of $\$ 8.08 / \mathrm{m}^{3}$ for ice storms and $\$ 28.11 / \mathrm{m}^{3}$ for hurricanes. From their work, debris removal costs would range between approximately $\$ 1,174,000$ to $\$ 4,083,000$ for the mean debris volume from this study.

Results from this study provide a method to rapidly and accurately estimate volumes of tree debris after an ice storm. Three different models were created and they vary in their application depending on community size and ice thickness. The models have greater likelihood to produce accurate results for regional areas than the smallest communities in this study. Application of study models will allow emergency managers and urban foresters to develop predictions of ice storm debris volumes following ice storms. These models could also be used to develop potential debris volume estimates prior to storms as part of storm damage preparedness planning. Local data for per unit debris removal costs and time requirements to remove debris can be used in conjunction with model estimates from this study to develop how much money and time is required to recover from ice storms of varying magnitude.

Acknowledgments. This research was supported through funding and cooperation from the United States Forest Service Southern Region, the University of Wisconsin - Stevens Point, and the Midwest Center for Urban and Community Forestry. We thank all communities who supported the development of the ice storm debris estimation models through their generous contribution of data which made completion of this study much easier. We also thank the advice and suggestions of three anonymous reviewers with the refinement of this paper.

\section{LITERATURE CITED}

Barber, B. 2008. Debris estimate rises sharply. Tulsa World. Accessed 3/14/2011. <www.tulsaworld.com/news/article. aspx?articleID=20080116_1_A1_spanc44663>

Bloniarz, D.V., H.D.P. Ryan III, C.J. Luley, J. Bond, and D.C. Hawkins. 2001. An initial storm damage assessment protocol for urban and community forests. USDA Forest Service, Northeast Center for Urban and Community Forestry, University of Massachusetts, Amherst. Accessed 3/14/2011. <www.umass.edu/urbantree/icestorm/pages/ StormAssessProtocol.doc $>$

Bond, J. 2005. Final report 2003 storm damage protocol implementation (OH-03-346). Accessed 3/14/2011. <www.itreetools.org/storm/ resources/2003\%20SDAP\%20Implementation.pdf> 20 pp.

Bruederle, L.P., and F.W. Stearns. 1985. Ice storm damage to a southern mesic Wisconsin forest. Bulletin Torrey Botanical Club 112:167-175.

Burban, L.L., and J.W. Andresen. 1994. Storms Over the Urban Forest: Planning, Responding, and Regreening - A Community Guide to Natural Disaster Relief. Miscellaneous Publication. United States Department of Agriculture, Forest Service, Northern Area State \& Private Forestry. Newtown Square, PA. 152 pp.
Call, D.A. 2010. Changes in ice storm impacts over time: 1886-2000. Weather, Climate and Society 2:23-35.

Changnon, S.A. 2003. Characteristics of ice storms in the United States. Journal of Applied Meteorology 42:630-639.

Changnon, S.A., and J.M. Changnon. 2002. Major ice storms in the United States, 1949-2000. Environmental Hazards 4:105-111.

Ciesla, W.M., W.R. Frament, and M. Miller-Weeks. 2001. Remote sensing techniques for rapid assessment of forest damage caused by catastrophic climatic events. NA-TP-01-01. United States Department of Agriculture, Forest Service, Northeastern Area, State \& Private Forestry. Newton Square, PA. 71 pp.

Cullen, S. 2002. Trees and wind: wind scales and speeds. Journal of Arboriculture 28:237-242

De Steven, D., J. Kline, and P.E. Matthiae. 1991. Long-term changes in a Wisconsin Fagus-Acer forest in relation to a glaze storm disturbance. Journal of Vegetation Science 2:201-208.

DeGaetano, A.T. 2000. Climatic perspectives and impacts of the 1998 northern New York and New England ice storm. Bulletin American Meteorological Society 81:237-254.

Dillman, D.A. 2007. Mail and internet surveys: the tailored design method second edition 2007 update with new internet, visual, and mixedmode guide. John Wiley and Sons, New York, NY. 523 pp.

Escobedo, F., C. Luley, J. Bond, C. Staudhammer, C. Bartel. 2009. A hurricane debris and damage assessment for Florida urban forests. Arboriculture \& Urban Forestry 35:100-106.

FEMA. 2007. Public assistance debris management guide. FEMA Publication \#325. Accessed 7/14/2010. <www.fema.gov/pdf/government/ grant/pa/demagde.pdf>

Francis, J.K., and A.J.R. Gillespie. 1993. Relating gust wind speed to tree damage in Hurricane Hugo, 1989. Journal of Arboriculture 19:368-373.

Godschalk, A., E. Rose Mittler, K. Porter, and C.T. West. 2009. Estimating the value of foresight: aggregate analysis of natural hazard mitigation benefits and costs. Journal of Environmental Planning and Management 52:739-756.

Greene, D.F., K.F., Jones, and O.J. Proulx. 2007. The effect of icing events on the death and regeneration of North American trees. In: E.A. Johnson and K. Miyanishi (Eds.). Plant Disturbance Ecology: The Process and the Response. Elsevier, Amsterdam. pp. 181-213.

Harshberger, J.W. 1904. The relation of ice storms to trees. Contributions from the Botanical Laboratory of the University of Pennsylvania 2:45-349.

Hauer, R.J., J.O. Dawson, and L.P. Werner. 2006. Trees and ice storms: The development of ice storm-resistant urban tree populations, Second Edition. Joint Publication 06-1, College of Natural Resources, University of Wisconsin-Stevens Point and the Department of Natural Resources and Environmental Sciences and the Office of Continuing Education, University of Illinois at Urbana-Champaign. 20 pp.

Hauer, R.J., and G.R. Johnson. 2003. Tree risk management. In: J. Pokorny (Ed.). Urban Tree Risk Management: A Community Guide to Program Design and Implementation. NA-TP-03-03. United States Department of Agriculture Forest Service. Newton Square, PA. pp. 5-10.

Hauer, R.J., W. Wang, and J.O. Dawson. 1993. Ice storm damage to urban trees. Journal of Arboriculture 19:187-193.

Heynen, N., and G. Lindsey. 2003. Correlations of urban forest canopy cover implications for local public works. Public Works Management \& Policy 8:33-47.

Hooper, M.C., K. Arii, and M.J. Lechowicz. 2001. Impact of a major ice storm on an old-growth hardwood forest. Canadian Journal of Botany 79:70-75. 
Houston, T.G., and S.A. Changnon. 2007. Freezing rain events: a major weather hazard in the conterminous U.S. Natural Hazards 40:485-494.

Irland, L.C. 2000. Ice storms and forest impacts. The Science of The Total Environment 262:231-242.

Jacobs, D.M. 2000. February 1994 ice storm: forest resource damage assessment in northern Mississippi. Resource Bulletin SRS-54. United States Department of Agriculture Forest Service, Southern Research Station. Ashville, NC. 11 pp.

James, K.R., N. Haritos, and P.K. Ades. 2006. Mechanical stability of trees under dynamic loads. American Journal of Botany 93:1522-1530.

Jones, K.F. 1996. Ice accretion in freezing rain. CRREL Report 96-2. Cold Regions Research and Engineering Laboratory. Hanover, NH. 22 pp.

Jones, K.F. 1998. A simple model for freezing rain ice loads. Atmospheric Research 46:87-97.

Kane, B. 2008. Tree failure following a windstorm in Brewster, Massachusetts, USA. Urban Forestry \& Urban Greening 7:15-23.

Kenderes, K., R. Aszalós, J. Ruff, Z. Barton, and T. Standovár. 2007. Effects of topography and tree stand characteristics on susceptibility of forests to natural disturbances (ice and wind) in the Börzsöny Mountains (Hungary). Community Ecology 8:209-220.

King, D.J., I. Olthof, P.K.E. Pellikka, E.D. Seed, C. Butson. 2007. Modeling and mapping damage to forests from an ice storm using remote sensing and environmental data. Natural Hazards 35:321-342.

Kraemer, M.J., and R.D. Nyland. 2009. Hardwood crown injuries and rebuilding following ice storms: a literature review. General Technical Report NRS-60. United States Department of Agriculture Forest Service, Northern Research Station. Newton Square, PA. 29 pp.

Lafon, C.W. 2004. Ice-storm disturbance and long-term forest dynamics in the Adirondack Mountains. Journal of Vegetation Science 15:267-276.

Lafon, C.W., D.Y. Graybeal, and K.H. Orvis. 1999. Patterns of ice accumulation and forest disturbance during two ice storms in southwestern Virginia. Physical Geography 20:97-115.

Liu, H., R.A. Davidson, T.V. Apanasovich. 2008. Spatial generalized linear mixed models of electrical power outages due to hurricanes and ice storms. Reliability Engineering and System Safety 93:875-890.

Luley, C.J., A. Pleninger, and S. Sisinni. 2002a. The effect of wind gusts on branch failures in the city of Rochester, New York, U.S. In: E.T. Smiley and K.D. Coder (Eds.) Tree Structure and Mechanics Conference Proceedings: How Trees Stand Up and Fall Down. International Society of Arboriculture and the ISA Southern Chapter, International Society of Arboriculture. Champaign, IL. pp. 103-109.

Luley, C.J., S. Sisinni., and A. Pleninger. 2002b. The effect of pruning on service requests, branch failures, and priority maintenance in the City of Rochester, New York, U.S. Journal of Arboriculture 28:137-143.

Melancon, S., and M.J. Lechowicz. 1987. Differences in the damage caused by glaze ice on codominant Acer saccharum and Fagus grandifolia. Canadian Journal of Botany 65:1157-1159.

Mertler, C.A., and R.A. Vannatta. 2005. Advanced Multivariate Statistical Methods. Third Edition. Pyrczak Publishing. Los Angeles, CA. 347 pp.

Millward, A.A., and C.E. Kraft. 2004. Physical influences of landscape on a large-extent ecological disturbance: the northeastern North American ice storm of 1998. Landscape Ecology 19:99-111.

Neter, J., W. Wasserman, and M.H. Kutner. 1990. Applied Linear Statistical Models: Regression, Analysis Of Variance, and Experimental Design. Third Edition. Richard Irwin, Inc. Homewood, IL. 1181 pp.

Nowak, D. 2010. Personal Communication. Urban Forest Data Interface. Accessed 3/14/2011. <http://nrs.fs.fed.us/data/urban>

Olthof, I., D.J. King, and R.A. Lautenschlager. 2004. Mapping deciduous forest ice storm damage using Landsat and environmental data. Remote Sensing of Environment 89:484-496.
Pasher, J., and D.J. King. 2006. Landscape fragmentation and ice storm damage in eastern Ontario forests. Landscape Ecology 21:477-483.

Proulx, O.J., and D.F. Greene. 2001. The relationship between ice thickness and northern hardwood tree damage during ice storms. Canadian Journal of Forest Research 31:1758-1767.

Rebertus, A.J., S.R. Shifley, R.H. Richards, and L.M. Roovers. 1997. Ice storm damage to an old-growth oak-hickory forest in Missouri. American Midland Naturalist 137:48-61.

Rhoads, A.G., S. P. Hamburg, T.J. Fahey, T.G. Siccama, E.N. Hane, J. Battles, C. Cogbill, J. Randall, and G. Wilson. 2002. Effects of an intense ice storm on the structure of a northern hardwood forest. Canadian Journal of Forest Research 32:1763-1775.

Rogers, W.E. 1922. Ice storms and trees. Torreya 22:61-63.

Ryall, K.L., and S.M. Smith. 2005. Patterns of damage and mortality in red pine plantations following a major ice storm. Canadian Journal of Forest Research 35:487-493.

Sander, H., S. Polasky, and R.G. Haight. 2010. The value of urban tree cover: A hedonic property price model in Ramsey and Dakota Counties, Minnesota, USA. Ecological Economics 69:1646-1656.

Sanzen-Baker, R.G., and M. Nimmo. 1941. Glazed frost 1940 - damage to forest trees in England and Wales. Forestry 15:37-54.

Scarr, T.A., A.A. Hopkin, and G.M. Howse. 2003. Aerial sketch-mapping of the 1998 ice storm in eastern Ontario. The Forestry Chronicle 79:91-98

Semonin, R.G. 1978. Severe weather climatology in the Midwest and arboriculture. Journal of Arboriculture 4:128-136.

Siccama, T.G., G. Weir, and K. Wallace. 1976. Ice damage in a mixed hardwood forest in Connecticut in relation to Vitis infestation. Bulletin of the Torrey Botanical Club 103:180-183.

Sisinni, S.M., W.C. Zipperer, and A.G. Pleninger. 1995. Impacts from a major ice storm: Street tree damage in Rochester, New York. Journal of Arboriculture 21:156-167.

Stueve, K.M., C.W. Lafon, and R.E. Isaacs. 2007. Spatial patterns of ice storm disturbance on a forested landscape in the Appalachian Mountains, Virginia. Area 39:20-30.

Van Dyke, O.R.P.F. Landmark Consulting. 1999. A literature review of ice storm impacts on forests in Eastern North America. Ontario Ministry of Natural Resources Southcentral Sciences Section Technical Report \#112. 28 pp.

Walton, J.T. 2008. Difficulties with estimating city-wide urban forest cover change from national, remotely-sensed tree canopy maps. Urban Ecosystems 11:81-90.

Walton, J.T., D.J. Nowak, and E.J. Greenfield. 2008. Assessing urban forest canopy cover using airborne or satellite imagery. Arboriculture and Urban Forestry 34:334-340.

Yip, T.C. 1995. Estimating icing amounts caused by freezing precipitation in Canada. Atmospheric Research 36:221-232.

Zipperer, W.C., S.M. Sisinni, J. Bond, C. Luley, and A.G. Pleninger. 2004. An assessment of management history of damaged and undamaged trees 8 Years after the ice storm in Rochester, New York, U.S. Journal of Arboriculture 30:92-100.

Zipperer, W.C., S.M. Sisinni, and R.V. Pouyat. 1997. Urban tree cover: an ecological perspective. Urban Ecosystems 1:229-246. 
Richard J. Hauer (corresponding author)

Associate Professor

University of Wisconsin - Stevens Point

College of Natural Resources

800 Reserve Street

Stevens Point, WI 54481, U.S.

rhauer@uwsp.edu

\section{Angela J. Hauer}

Program Associate

University of Wisconsin - Stevens Point

Wisconsin Institute for Sustainable Technology

2001 Fourth Avenue

Stevens Point, WI 54481, U.S.

Dudley R. Hartel

Center Manager

Urban Forestry South

USDA Forest Service

Integrating Human \& Natural Systems (SRS-4952)

320 Green Street

Athens, GA 30602, U.S.

Jill R. Johnson

Coordinator

Midwest Urban Forestry Coordinator

USDA Forest Service

1992 Follwell Avenue

Saint Paul, MN 55108, U.S.
Résumé. cet article présente une méthode d'évaluation rapide pour estimer le volume de débris qui suit une tempête de verglas. Les données ont été recueillies auprès de 60 communautés afin de quantifier les volumes de débris (la plupart d'emprises publiques de réseaux aériens) qui étaient présents suite à une tempête de verglas, et ce en se basant sur l'infrastructure de la communauté, les paramètres climatiques et la structure de la forêt urbaine. L'épaisseur de glace, la superficie de la communauté et la distance entre les rues sont des variables significatives de prédiction pour estimer les volumes de débris provenant des tempêtes de verglas. Les résultats de cette étude fournissent un moyen pour estimer le volume des débris ligneux provenant des arbres urbains immédiatement après une tempête de verglas. Ce modèle peut aussi être utilisé pour prédire le volume de débris dans le cadre d'une planification préventive.

Zusammenfassung. Diese Studie präsentiert eine schnelle Untersuchungsmethode zur Abschätzung von Baumabfällen nach einem Eissturm. Es wurden Daten aus 60 Kommunen gesammelt, um dieVolumina der Baumabfälle nach einem Eissturm zu quantifizieren, meistens aus Bereichen der öffentlichen Wege, basierend auf Daten zur Infrastruktur, Wetterparametern und urbaner Forststrukturen. Die Eismächtigkeit, die betroffene Fläche innerhalb der Kommune und die Distanz zur Strasse sind signifikante Parameter für die Schätzung der anfallenden Baumreste. Die Ergebnisse aus dieser Studie liefern eine Möglichkeit, das Volumen der Holzabfälle von Strassenbäumen direkt nach einem Sturm zu schätzen. Das Modell kann ebenso verwendet werden, um vor Stürmen bereits Vorbereitungen zu treffen.

Resumen. Este reporte presenta un mètodo de evaluaciòn ràpido para estimar los desechos del àrbol urbano despuès de una tormenta. Se colectaron datos de 60 comunidades para cuantificar los volùmenes de desechos, principalmente de àreas pùblicas de derecho de vìa, despuès de tormentas de hielo con base en la infraestructura comunitaria, paràmetros del clima y estructura del bosque urbano. El espesor del hielo, área de la comunidad, y distancia a la calle son predictores significativos para estimar los desechos de las tormentas. Los resultados de este estudio proven una forma de estimar los volùmenes de desechos de los àrboles urbanos inmediatamente despuès de una tormenta de hielo. El modelo tambièn puede ser usado para predecir los volùmenes de desechos para proyectos de planeaciòn. 
APPENDIX. DATA VARIABLES AND DEFINITION, INFORMATION COLLECTED, SOURCE OF DATA, AND UNIT OF MEASURE.

\begin{tabular}{|c|c|c|}
\hline Variable: Definition & Data Source & Unit of Measure \\
\hline \multicolumn{3}{|l|}{ Debris Volume (Dependent) } \\
\hline Private Debris: Tree debris reported from private land & Questionnaire $^{\mathrm{z}}$ & $\mathrm{m}^{3}$ \\
\hline Public Debris: Tree debris reported from public land & Questionnaire & $\mathrm{m}^{3}$ \\
\hline Total Debris: Tree debris reported from community & Questionnaire & $\mathrm{m}^{3}$ \\
\hline \multicolumn{3}{|l|}{ Community Infrastructure (Independent) } \\
\hline Street Distance: Public linear street distance in community & Questionnaire & $\mathrm{km}$ \\
\hline Land Area: Total land area within political boundary & Questionnaire & $\mathrm{km}^{2}$ \\
\hline NLCD Land Area: Total land area within political boundary & $\mathrm{NLCD}^{\mathrm{y}}$ & $\mathrm{km}^{2}$ \\
\hline Developed Land Area: Total developed within the political boundary & NLCD & $\mathrm{km}^{2}$ \\
\hline Population 2000: People living in community in year 2000 & NLCD & \# \\
\hline \multicolumn{3}{|l|}{ Urban Forest Attributes (Independent) } \\
\hline Canopy Cover: Tree canopy in community over all land area & Questionnaire & $\%$ \\
\hline NLCD Canopy Cover: Tree canopy in community over all land area & NLCD & $\%$ \\
\hline \multicolumn{3}{|l|}{ Weather Dynamics (Independent) } \\
\hline Ice Thickness: Accumulation of ice as measured in diameter & Questionnaire & $\mathrm{cm}$ \\
\hline Maximum Wind Speed: Highest recorded wind during ice storm & Questionnaire & $\mathrm{km} / \mathrm{h}$ \\
\hline
\end{tabular}

${ }^{\mathrm{z}}$ Data reported by community from 2010 questionnaire collected from this study.

${ }^{y}$ Data compiled from 2001 NLCD (http://nrs.fs.fed.us/data/urban) (Nowak 2010). 